\title{
Plano de cargos, carreira e remuneração em Boa Vista (RR): \\ análise da valorização do trabalho docente ${ }^{1}$
}

\author{
Maria Angélica Pedra Minhoto \\ mminhoto@gmail.com
}

\begin{abstract}
Resumo
Este texto tem como objetivo analisar o atual Plano de Cargos, Carreira e Remuneração do magistério público da cidade de Boa Vista, município da capital do Estado de Roraima. Em consonância com os objetivos da pesquisa nacional, o artigo visa analisar a estrutura da remuneração e da carreira dos professores boa-vistenses, no intuito de contribuir para revelar a diversidade de realização das políticas que declaram valorizar os docentes e melhorar os mecanismos de financiamento da educação $\mathrm{O}$ foco na remuneração e nas condições de trabalho dos professores justifica-se pelo papel de destaque desses profissionais na promoção da qualidade da educação e das instituições educacionais.
\end{abstract}

Palavras-chave: Remuneração e carreira docentes; valorização do magistério; condições de trabalho docente.

\footnotetext{
1 Embora a responsabilidade pelo artigo seja da autora, o texto contou com contribuições da equipe de pesquisadores de São Paulo: Prof. Dr. Rubens Barbosa de Camargo (USP), Profa. Dra. Lisete Regina Gomes Arelaro (USP), Profa. Dra. Márcia Aparecida Jacomini (UNIFESP), Ms. Adriana Inácio Yanaguita (Doutoranda - UNESP/Marília), Ms Kátia Aparecida Santos (Auxiliar de Pesquisa - Professora da rede municipal/SP), Nilson Alves de Souza (Mestrando - USP), Ana Paula Santiago Nascimento (Mestranda - USP), Flávio Pinto Silva (IC-USP, até outubro/2010), Renata Rodrigues de Amorim Medina (IC-USP, desde julho/2010) e Claudia Alves Pereira (Auxiliar de Pesquisa - Professora rede estadual/SP, após outubro/2010).

2 Doutora em Educação pela Pontifícia Universidade Católica de São Paulo, Brasil (2007). Professora da Universidade Federal de São Paulo.
} 


\section{Introdução}

Este texto tem como objetivo analisar o atual Plano de Cargos, Carreira e Remuneração (PCCR) do magistério público da cidade de Boa Vista, município da capital do Estado de Roraima, instituído recentemente pela Lei $n^{\circ} 1.145$, de 20 de maio de 2009, em substituição à Lei n ${ }^{\circ} 714$, de 10 de dezembro de 2003, que anteriormente regulava a carreira.

Em consonância com os objetivos da pesquisa nacional, o artigo visa analisar a estrutura da remuneração e da carreira dos professores boa-vistenses, no intuito de contribuir para revelar a diversidade de realização das políticas que declaram valorizar os docentes e melhorar os mecanismos de financiamento da educação como, por exemplo, as que instituíram as reformas educacionais, a partir de meados da década de 1990, o Fundef (Lei no 9.424/96), o Fundeb (Lei no 11.494/2007), o Piso Salarial Profissional Nacional (Lei $n^{0} 11.738 / 2008$ ), as Diretrizes Nacionais para os Planos de Carreira e Remuneração dos Profissionais do Magistério da Educação Básica Pública (Parecer CNE/CEB nº 9/2009).

$O$ foco na remuneração e nas condições de trabalho dos professores justifica-se pelo papel de destaque desses profissionais na promoção da qualidade da educação e das instituições educacionais. Várias pesquisas sobre o custo-aluno-qualidade na Educação Básica mostram que os gastos com pessoal, computados como salários, constituem a parte mais significativa dos investimentos em educação (PARO, 1982; LUCE \& FARENZENA, 1998; PINTO, 2006; GOUVEIA, CRUZ, OLIVEIRA \& CAMARGO, 2006). O trabalho docente, como uma especialidade profissional, e a luta por sua valorização podem ser inferidos tendo em vista o histórico de estabelecimento de estatutos e planos de carreira, estruturando a profissão, e das lutas de grupos organizados da sociedade civil que visam à melhoria dos salários e das condições de trabalho.

Vale destacar que os sistemas públicos de ensino são, atualmente, um dos setores sociais que mais oferecem oportunidades de emprego formal para a população. De acordo com Gatti e Barreto (2009):

Do total de empregos registrados em 2006, 8,4\% destinavam-se a professores, conforme informa a Rais, sendo que, quanto ao volume de emprego, 
os professores situavam-se no terceiro lugar no ranking de subconjuntos de ocupações $(. . .)^{3}$. Em 2006 existiam, segundo a Rais, 2.949.428 postos de trabalho para professores e outros profissionais de ensino, sendo que $82,6 \%$ deles provinham de estabelecimentos públicos. Essa enorme massa de empregos na esfera pública, provavelmente uma das maiores do mundo, tem óbvios desdobramentos em termos do financiamento do setor educacional, dos salários, das carreiras e das condições de trabalho docente, além, evidentemente, das repercussões na qualidade do ensino ofertado. (GATTI; BARRETO, 2009, p.16).

Ainda segundo as autoras, do total de postos de trabalho existentes para os professores, em 2006, 73\% destinavam-se aos docentes da educação básica, ou 2.159.269 postos. Discutir, portanto, os planos de carreira, cargos e remuneração de parte desse enorme contingente de profissionais é compreender como e se realmente têm funcionado os mecanismos que visam à valorização docente.

Não são novos os debates acerca das estruturas de carreira e dos sistemas de remuneração do magistério. Na verdade, antecedem em muito às recentes iniciativas de reforma educacional, ocorridas em boa parte das nações ocidentais nas últimas décadas do século XX. A título de exemplo, em importante documento da OIT/UNESCO, publicado em 1966, intitulado Recomendación relativa a la situación del personal docente, já tinham sido definidas recomendações internacionais concernentes à condição e ao status da profissão docente, reconhecido o papel essencial desse profissional para o progresso e a qualidade da educação e anunciada a importância de sua contribuição para o desenvolvimento da sociedade moderna (OIT/UNESCO, 1966).

Em linhas gerais, o documento propugna por melhores condições de trabalho para esses profissionais com vistas a um ensino eficaz e à possibilidade de dedicação plena às tarefas relativas à promoção de uma

3 Rais significa Relação Anual de Informações Sociais. É um instrumento de coleta de dados do Ministério do Trabalho e Emprego que tem por objetivo controlar as atividades trabalhistas no país, provendo dados para a elaboração de estatísticas e informações do mercado de trabalho às entidades governamentais. 
educação de qualidade. Dentre outros fatores, destaca a remuneração como forma de avaliar a condição do trabalho docente, revelando preocupação com a situação econômica desse grupo profissional e a importância de assegurar um nível de vida satisfatório, para que, sem descuidar das necessidades familiares, os professores tenham recursos suficientes para aperfeiçoar seu desempenho e sua qualidade profissional. No que se refere às diferenças salariais entre os docentes, $\mathrm{o}$ documento já destacava que devem ser determinadas a partir de critérios objetivos, como qualificação, idade e experiência. Aos profissionais sem qualquer grau acadêmico, defende que os governos levem em consideração o valor da prática e da experiência dos professores, além de manifestar-se favoravelmente à revisão periódica da remuneração docente, considerando fatores como aumento do custo de vida, melhoria das condições de trabalho, formação continuada e outros rendimentos materiais dignos para esses profissionais.

Tomando essa perspectiva progressista como referência de análise e para cumprir os objetivos propostos, o grupo de Pesquisa do Observatório da Remuneração Docente tem investigado e apontado, em diferentes locais do Brasil, as características atuais, presentes nos planos de carreira, no que toca: 1) às condições de trabalho dos professores, tal como as diversas jornadas de trabalho, sua duração e composição, a definição da hora-atividade, as formas de licença e o estímulo à qualificação; 2) aos critérios de ingresso na profissão, como o grau de formação necessário, os concursos e as provas; 3) à evolução funcional, por tempo de serviço, avaliação de desempenho, atividades de formação continuada, titulação ou provas de conhecimento; 4) à composição da remuneração do magistério público, como seu vencimento básico e os diversos adicionais e auxílios, que podem ser ou não incorporados à aposentadoria; a análise da dispersão da remuneração, desde o ingresso até o topo da carreira; e seu impacto na atratividade para o ingresso na profissão docente. Como consequência, pretende reconhecer os traços que afetam a satisfação dos profissionais com a carreira e o estímulo dado aos jovens para que venham a se tornar docentes, uma profissão considerada, neste texto, como um dos pilares centrais do 
processo educativo, com importante impacto na qualidade e no grau de aprendizagem nos diversos níveis e modalidades de ensino.

Entretanto, antes de expor o produto das análises do PCCR do magistério de Boa Vista, vale destacar algumas características específicas da cidade e de seu atendimento educacional, como forma de contextualizar os resultados do estudo em tela, o que se fará a seguir.

\section{Boa Vista e o Sistema Municipal de Educação}

Boa Vista está situada na Região Norte do país e é a capital do Estado de Roraima, antigo Território Federal que ganha status de Estado em 1988, com a promulgação da Constituição Federal. O Estado de Roraima foi de fato implantado em janeiro de 1991, passando então por inúmeras transformações para organizar a sua estrutura de governo.

De acordo com informações disponíveis no sítio da Prefeitura de Boa Vista ${ }^{4}$, a partir da década de 1980, começa a haver uma forte expansão demográfica na cidade com processos de imigração motivados pela descoberta do garimpo. Para se ter uma ideia da expansão populacional da cidade, em 1950, Boa Vista tinha 5.132 habitantes e, segundo o IBGE, esse número, hoje, (2009) chega a 266.901 habitantes, um crescimento significativo em 60 anos (mais de $5.100 \%$ ), revelando um rápido e intenso processo de urbanização. Além do extrativismo, a economia da cidade assenta-se principalmente no setor de serviços e na agropecuária.

O crescimento demográfico trouxe, para os governos estadual e municipal, diversas demandas por serviços públicos, entre os quais a educação, o que tem exigido a ampliação de oferta de vagas nas escolas e a contratação de novos docentes para efetivação desse direito. No caso do atendimento na rede municipal de Boa Vista, na última década, houve um crescimento importante no número de matrículas em creches (triplicou), pré-escolas (quadruplicou) e nas primeiras séries do ensino fundamental (mais que triplicou), apesar de alguma inconstância no ritmo desse crescimento, como evidenciado na TAB. 1 abaixo: 


\section{TABELA 1}

Evolução das matrículas na rede municipal de ensino de Boa Vista/RR (1999-2009)

\begin{tabular}{c|c|c|c|c|c|c|c|c|c|c|c}
\cline { 2 - 11 } Matrícula & $\mathbf{1 9 9 9}$ & $\mathbf{2 0 0 0}$ & $\mathbf{2 0 0 1}$ & $\mathbf{2 0 0 2}$ & $\mathbf{2 0 0 3}$ & $\mathbf{2 0 0 4}$ & $\mathbf{2 0 0 5}$ & $\mathbf{2 0 0 6}$ & $\mathbf{2 0 0 7}$ & $\mathbf{2 0 0 8}$ & $\mathbf{2 0 0 9}$ \\
\hline Creche & 0 & 192 & 187 & 328 & 527 & 552 & 638 & 762 & 580 & 673 & 577 \\
Pré-escola & 1345 & 2184 & 2626 & 2128 & 2059 & 3286 & 2162 & 2230 & 2.710 & 5.750 & 6.194 \\
$1^{\text {a a }} 4^{\text {a }}$ série & - & 3.373 & 4.167 & 4.416 & 4.564 & 5.070 & 7.333 & 7525 & 8.355 & 11.846 & 12.307 \\
\hline
\end{tabular}

Fonte: MEC/INEP: Sinopses Estatísticas da Educação Básica.

De acordo com Souza, Santos e Souza (2008), Boa Vista concentra as principais atividades produtivas de Roraima e é o principal núcleo urbano do Estado. O dinamismo da cidade "depende fortemente do setor público, que opera como o principal investidor e empregador. O PIB do Município tem sido alavancado pelo setor terciário, graças à forte participação do setor público" (SOUZA; SANTOS; SOUZA, 2008, p. 89). A cidade está, atualmente, em fase de médio desenvolvimento humano, segundo os autores, que mostram o fator educação como decisivo para o crescimento do Índice Municipal de Desenvolvimento Humano (IDH-M), entre 1991 e 2000. Infelizmente, o estudo não encontrou o mesmo resultado quanto ao fator renda, com participação mínima na melhoria do índice ${ }^{5}$.

Apesar de classificada em nível médio de desenvolvimento humano, Boa Vista é uma cidade marcada pela desigualdade social. O rápido crescimento demográfico que exigiu novas políticas de atendimento e proteção social à população não produziu alternativas que incluíssem, de fato, os habitantes tradicionais da região - grupos indígenas -, que hoje ocupam a periferia da cidade e têm acesso limitado aos bens e serviços. Boa Vista pode ser considerada uma metrópole pobre, pois mais de $50 \%$ de sua população vive abaixo da linha de pobreza, segundo Souza (2009, p. 67), informando que "a renda média de um trabalhador está entre um e três salários mínimos, sendo que apenas 32,75\% dos trabalhadores têm rendimento mensal superior a três salários mínimos".

5 O IDH-M tem metodologia de cálculo similar à do Índice de Desenvolvimento Humano (IDH), mas sua unidade de análise é o município. O índice pretende contribuir para a avaliação das condições de vida local, utilizando informações dos censos demográficos, a respeito da educação, da saúde e da renda da população. 
Em relação às condições de trabalho da população, mais da metade da mão de obra de Boa Vista $(51,1 \%)$ realiza suas atividades no setor informal, segundo Saboia e Saboia (2004), situação que se caracteriza pela ausência de contrato oficial de trabalho e contribuição previdenciária. São indivíduos que não possuem qualquer proteção da legislação trabalhista ou previdenciária e sua inserção no mercado é bastante precária.

Em relação ao Sistema Municipal de Educação, foi instituído oficialmente em 6 de junho de 2005, com a promulgação da Lei $n^{\circ} 784$. Compreende a Secretaria Municipal de Educação e Cultura (SEMEC); o Conselho Municipal de Educação (CME); o Plano Municipal de Educação; as instituições de ensino fundamental e de educação infantil, criadas e mantida pelo Poder Público Municipal; e as de educação infantil, criadas e mantidas pela iniciativa privada; o Conselho Municipal de Acompanhamento e Controle Social do Fundo de Manutenção e Desenvolvimento do Ensino Fundamental e de Valorização do Magistério (Fundef $^{6}$; o Conselho Municipal de Alimentação Escolar e os projetos educativos de natureza especial (art. 13).

Entretanto, antes da instituição formal do sistema de ensino, em 2005, a rede de escolas municipais já funcionava de maneira organizada, desde, pelo menos, $1990^{7}$, e há registro de servidores municipais atuando em escolas da rede, que apresentam data de admissão no ano de 1985 (cf. Decreto $n^{0}$ 2025/P, de 20 de agosto de 2009). Em relação à estrutura e organização da carreira do magistério municipal, o primeiro estatuto da categoria data de 1992 (Lei $\mathrm{n}^{\circ} 282$ ), modificado após seis anos pela Lei $n^{\circ} 451$, de 17 de março de 1998. No final de 2003, foi sancionada nova lei (Lei $n^{\circ} 714$ ), reorganizando a carreira e, em 2009, foi estabelecido o atual Plano de Carreira Cargos e Remuneração (PCCR).

Não é possível estabelecer, nesses documentos, uma distinção clara entre estatuto e plano de carreira, considerando que o primeiro deveria corresponder "ao conjunto de normas que regulam a relação funcional dos servidores com a administração pública, e dispor sobre

6 Atual Conselho Municipal de Acompanhamento e Controle Social do Fundo de Manutenção e Desenvolvimento da Educação Básica e de Valorização dos Profissionais da Educação (Fundeb).

7 Informações coletadas em entrevista com Sueli Moraes da Silva Cardozo, presidente do Sindicato dos Trabalhadores Municipais de Boa Vista (Sitram). 
investidura, exercício, direitos, vantagens, deveres e responsabilidades" (DUTRA JÚNIOR et al., 2000, p. 36), isto é, a forma de ingresso na carreira e as etapas que devem ocorrer até o início das atividades do profissional, as regras relativas ao estágio probatório, o tempo de serviço, a aposentadoria, as férias, a remuneração, o direito à greve, os deveres e punições aplicáveis. Já o plano de carreira deveria consistir das normas que "definem e regulam as condições e o processo de movimentação dos integrantes, em uma determinada carreira, e estabelecer a progressão funcional e a correspondente evolução da remuneração", sendo a carreira considerada como a "organização dos cargos de determinada atividade profissional em posições escalonadas em linha ascendente" (DUTRA JÚNIOR et. al., 2000, p. 36). Na verdade, todas as leis mencionadas são documentos únicos que dispõem, ao mesmo tempo, em maior ou menor grau, sobre o estatuto e o plano de carreira do magistério boa-vistense.

Entre outras atribuições, a SEMEC é responsável por propor atualizações no plano de carreira, ouvindo os profissionais da educação, em articulação com o CME (Lei n ${ }^{0} 784$, art. 14, inciso VIII), visando assegurar o princípio da "valorização dos profissionais da educação escolar", conforme estabelecido no art. $7^{\circ}$, inciso VII da referida lei.

Atualmente, a rede municipal de Boa Vista dispõe de 72 escolas em funcionamento, sendo 68 localizadas na zona urbana e quatro na zona rural. Entre elas, 43 oferecem Ensino Fundamental (EF) e 50 oferecem Educação Infantil, em creches e pré-escolas, atendendo a 12.497 crianças e jovens matriculados no EF e a 6.234 crianças na Educação Infantil (EI), cobrindo, respectivamente, $24,0 \%$ e $81,5 \%$ do atendimento da cidade para essas etapas de ensino. De acordo com os dados do Censo Escolar (2009), o Sistema Municipal emprega 1.191 docentes, dos quais 740 atuam no EF, 335 na EI e 116 em outras modalidades de ensino. A rede municipal é responsável por empregar $37,5 \%$ dos professores que trabalham até o nono ano do EF, na cidade de Boa Vista 8 .

De acordo com os dados do Censo Escolar de 2009, a rede municipal de Boa Vista emprega 1.017 mulheres, o que corresponde a mais de $85 \%$

8 Dados do MEC/INEP, disponíveis em http:/ / www.ibge.gov.br/cidadesat/link.php?uf=rr, acessado em 29/10/2010 e dados do Censo Escolar de 2009, disponíveis em http:/ / www.inep.gov.br/bittorrent/ microdados/micro_censo_escolar2009 .zip, acessado em 30/08/2010. 
do total de seus professores. Em termos de raça, mais de $42 \%$ dos docentes não declararam a sua cor (505 docentes) - entre os que o fizeram $42 \%$ consideram-se pardos (500 professores), $12 \%$ brancos (145 docentes), $2 \%$ pretos (21 professores), 1,5\% indígenas (18 docentes) e 0,2\% amarelos (dois professores).

No que toca à escolaridade, mais de $67 \%$ dos professores possuem o nível médio completo de escolarização (803 professores), distribuídos entre Magistério (641), o Ensino Médio regular (159) e Magistério indígena (3); 32\% possuem nível superior completo (381 docentes) e apenas sete professores apresentam fundamental completo $(0,6 \%)$ entre estes, quatro trabalham na zona rural, em escolas indígenas, e três declararam-se índios. Em termos de pós-graduação, 89 docentes declaram ter especialização, o que representa apenas 7,5\% dos professores, não há mestres ou doutores na rede. Outro dado interessante é a idade dos docentes, que mostra ser a rede relativamente nova: $50 \%$ dos docentes têm até 33 anos de idade. Ao agruparmos os professores por faixas etárias temos que apenas 1,1\% apresentam idades até 20 anos; 35,7\% têm entre 21 e 30 anos; 40,6\% têm entre 31 e 40 anos; $19 \%$ têm entre 41 e 50 anos e $3,6 \%$ têm mais de 51 anos.

Os dados sobre o nível de escolarização dos docentes são importantes, pois além de colocarem a questão da qualificação em nível superior como um ponto importante na pauta que deve mobilizar a política educacional de Boa Vista - uma rede que precisa proporcionar formação superior a quase $70 \%$ de seus servidores -, evidenciam o enquadramento funcional dos docentes no atual plano de carreira, que tem como base a titulação acadêmica. Junto com os dados referentes à idade, é possível fazer algumas inferências a respeito da duração da vida profissional do grupo magistério e da perspectiva que têm de alcançarem posições mais próximas ao topo da carreira, o que se fará em item posterior deste texto.

Com o novo PCCR de Boa Vista, instituído em maio e implementado em setembro de 2009, o quadro de cargos de provimento efetivo de professor da educação municipal passou a ter 2.500 vagas para Educação Básica, abrangendo o Ensino Fundamental, a Educação Infantil, a Educação Especial, o primeiro segmento da Educação de Jovens e 
Adultos e o Ensino Fundamental Indígena, ou seja, ampliou o número de vagas em $28 \%$ em relação à ocupação efetiva de 2009, tendo em vista que, de acordo com os dados do Censo Educacional de 2009, existiam 1.956 postos de trabalho ocupados na rede.

\section{Condições de trabalho dos professores de Boa Vista: orientações do PCCR ${ }^{9}$}

De acordo com as prescrições contidas no PCCR, o trabalho dos professores é composto pelas seguintes atribuições formais: ministrar os dias letivos e as horas de aula estabelecidas na legislação; participar da proposta pedagógica da escola; elaborar e cumprir planos de trabalho; zelar pela aprendizagem dos alunos, estabelecendo e implementando estratégias de recuperação paralela; participar integralmente dos períodos dedicados ao planejamento e à avaliação pedagógica; colaborar com a administração da escola; participar de reuniões pedagógicas e de iniciativas de articulação com a comunidade; buscar o aperfeiçoamento profissional e a formação continuada.

Para o desempenho de suas atividades, o professor é contratado por uma jornada de 25 horas semanais, das quais despende, no máximo, 20 horas em sala de aula, sendo o restante distribuído em atividades pedagógicas, cumpridas conforme a proposta de cada unidade escolar. Se por um lado essa forma de organização da jornada do professor está nitidamente vinculada à carga-horária regular dos estudantes, com 20 horas do trabalho do professor em sala de aula, por outro permite incorporar à sua jornada períodos de aperfeiçoamento profissional, o que lhe garante a remuneração para realizar tais atividades.

O estabelecimento das 25 horas de jornada e da composição do tempo de trabalho do professor é fato recente, em Boa Vista, presente no atual PCCR, já que no plano anterior (2003) não havia qualquer menção acerca

9 A regulamentação da carreira e da remuneração do magistério de Boa Vista, aqui descrita, bem como os conceitos utilizados para essa descrição - tais como grupo ocupacional, progressão salarial, promoção funcional, categoria ou faixa salarial, remuneração - têm como base a Lei n ${ }^{\circ} 1.145$, de 20 de maio de 2009, que dispõe sobre a estrutura de cargos, carreira e remuneração do quadro de provimento efetivo do professor público da educação básica da prefeitura municipal de Boa Vista, e a Lei no 458 , de 01 de junho de 1998, que dispõe sobre o regime jurídico dos servidores públicos civis do município e das suas fundações. 
dessa distribuição de carga-horária, além de apresentar dois tipos de jornada, atualmente extintas: de 20 e de 30 horas semanais. Apesar de existirem duas jornadas, a contratação dos profissionais, antes de 2009, dava-se apenas em regime de 30 horas semanais e a alteração para 25 horas expressa uma conquista, na medida em que não implicou perdas salariais.

Apesar disso, a atual jornada de trabalho de 25 horas não segue exatamente as prescrições da Resolução $n^{0} 2 / 2009$ e do Parecer $n^{0}$ 9/2009, ambos do CEB/CNE, que prevêem uma jornada de trabalho preferencialmente em tempo integral, de no máximo 40 horas semanais, com incentivo à dedicação exclusiva em uma única unidade escolar, como instrumento importante para a qualificação e continuidade do projeto político-pedagógico da instituição. As jornadas parciais induzem os docentes ao duplo emprego, o que pode fazer com que a jornada de trabalho final ultrapasse o limite constitucional de 44 horas semanais (CF $/ 88$, art. $\left.7^{\circ}, \mathrm{XIII}\right)$, válido para a maioria dos trabalhadores brasileiros, no entanto, em acordo com o inciso XVI do art. 37 da Emenda Constitucional n 19, que veda "a acumulação remunerada de cargos públicos, exceto, quando houver compatibilidade de horários, observado em qualquer caso o disposto no inciso XI: a) a de dois cargos de professor; b) a de um cargo de professor com outro, técnico ou científico; c) a de dois cargos privativos de médico" (BRASIL, 1998). A jornada de 25 horas pode, assim, ser considerada como um avanço em relação à jornada anterior, pois permite, ao menos aos professores da EI e dos anos iniciais do EF, exercerem integralmente a docência, no caso de precisarem acumular dois cargos, na própria rede ou mesmo em outras redes de ensino, fato extremamente comum aos docentes da rede municipal, que costumam acumular cargo, principalmente na rede estadual.

Vale destacar, contudo, que a organização da jornada que permite o exercício em dois cargos distintos revela o processo de desvalorização salarial e de desqualificação da profissão, na medida em que gera uma sobrecarga de trabalho para os docentes. Além disso, a fixação de uma única jornada de 25 horas, no PCCR de Boa Vista, permite inferir, que se for instituído o EF em tempo integral, não haverá contratação de professores em regime de dedicação exclusiva, com jornada de 40 horas semanais, 
cumprida em um único estabelecimento escolar, mas a contratação de dois professores ou a dupla jornada de um mesmo professor ${ }^{10}$.

Como o ocupante de um único cargo é impedido de exercer a docência integral em duas turmas de 20 horas-aula, que acrescidas de 10 horas-atividade totalizariam 50 horas de trabalho semanal, no caso de Boa Vista, ultrapassando o limite máximo de 40 horas do regime de dedicação exclusiva (DE), é certo que os investimentos para a manutenção da rede se elevariam com a adoção do regime DE. Entretanto, a jornada de 40 horas viabilizaria a profissionalização do magistério boa-vistense, tornando a docência a atividade principal e não secundária em relação a outro trabalho remunerado, contribuindo efetivamente para a garantia de uma escola pública de melhor qualidade.

Apesar de considerar-se, aqui, a jornada de 25 horas um avanço em relação à situação anterior, o plano não faz qualquer mediação acerca das condições em que as atividades de dentro e de fora de sala de aula devem acontecer, tal como a definição do número máximo de alunos por turma ou docente, tanto na EI como no EF, aspecto essencial à garantia de boas condições de trabalho e da qualidade do processo educativo, ou mesmo a respeito das condições para a qualificação profissional, em cursos de formação inicial e continuada. Não menciona, também, qualquer regra que garanta uma gestão democrática, como a participação dos professores em conselhos da escola ou a forma de provimento do cargo de direção, um posto que, na rede municipal de Boa Vista, é preenchido em regime de comissão - assim como as funções destinadas ao suporte pedagógico, administração escolar, planejamento educacional, inspeção, supervisão, orientação educacional e coordenação pedagógica.

Vale lembrar, ainda, que, pela Lei do Piso Salarial Profissional Nacional (Lei $\left.n^{0} 11.738 / 2008\right)$, o tempo para a realização de atividades extraclasse deve ser de $1 / 3$ da jornada de trabalho docente, o que equivaleria, na rede municipal de Boa Vista, a mais de 8 horas semanais dedicadas à formação,

10 A LDB afirma a importância do ensino fundamental integral como fundamento para o pleno desenvolvimento do educando (Art. $34, \S 2^{\circ}$ ), postulando que "o ensino fundamental será ministrado progressivamente em tempo integral, a critério dos sistemas de ensino". Sueli Moraes da Silva Cardozo, presidente do Sitram, informou que o debate sobre a instituição do ensino fundamental integral, com a jornada de dedicação exclusiva do professor, precisa avançar em Boa Vista e que há, atualmente, na rede municipal, o atendimento aos alunos em contraturno, com um projeto dedicado ao letramento. 
planejamento, trabalho coletivo etc. Infelizmente, Roraima foi um dos Estados que apoiou a Ação Direta de Inconstitucionalidade (ADIN) contra a Lei do Piso, movida pelos governadores dos Estados do Mato Grosso do Sul, Paraná, Santa Catarina, Rio Grande do Sul e Ceará, o que pode ter impactado a definição da composição da jornada, na rede municipal.

Em termos de licenças e afastamentos, o docente pode fazer jus a 11 modalidades distintas, previstas constitucionalmente. Pode licenciarse por doença em membros da família (cônjuge ou companheiro, pais, filhos, padrasto ou madrasta e enteado ou dependente que viva às suas expensas), somente quando sua assistência direta for indispensável e não puder ser prestada, simultaneamente, ao exercício de sua função ou compensação de horário. Quando o afastamento exceder os 90 dias, o servidor passa a receber apenas 2/3 de sua remuneração, após 180 dias de afastamento, a remuneração cai para 1/3 e se ultrapassar 365 dias o servidor fica sem remuneração, até o máximo de 730 dias.

O professor pode licenciar-se, também, por assiduidade, após cinco anos ininterruptos de exercício exclusivamente no Município. É a chamada licença-prêmio, que dá direito a três meses de afastamento, com todas as vantagens do cargo efetivo. Os períodos de licença-prêmio não são acumuláveis e, no caso de não serem gozados, são automaticamente incorporadas à contagem de tempo de serviço, em dobro, para efeito de aposentadoria. Se, por acaso, os períodos de licença-prêmio já tiverem sido adquiridos, mas não gozados pelo servidor que vier a falecer, são convertidos em pecúnia, em favor dos beneficiários da pensão.

O professor pode licenciar-se, ainda, para o desempenho de mandato no sindicato representativo da categoria, fazendo jus à sua remuneração, desde que considerado o máximo de dois servidores por entidade. A licença tem duração igual à do mandato, podendo ser prorrogada, no caso de reeleição, por uma única vez. Além disso, o servidor pode afastar-se para acompanhar seu cônjuge ou companheiro quando deslocado para outro ponto do país, para o exterior ou para o exercício de mandato eletivo dos Poderes Executivo e Legislativo. Essa licença não é remunerada, tem a duração do afastamento do cônjuge ou companheiro, deve ser renovada a cada dois anos e não é computada como tempo de serviço. 
A título de benefícios sociais, o professor tem direito, ainda, às seguintes licenças: para tratamento de saúde, licença-gestante, adotante, licença-paternidade e licença por acidente em serviço. Outras modalidades de licença são para o serviço militar, para o exercício de cargos eletivos e para tratar de interesses particulares, esta última, por um período de dois anos, renováveis uma única vez. A lei que normaliza as licenças do professor é a mesma que dispõe sobre o regime jurídico dos servidores públicos civis de Boa Vista (Lei 458/98, art. 80 ao art. 96 e art. 182) e concede, também, alguns afastamentos aos servidores.

É permitido ao servidor estável, por exemplo, o afastamento para os cursos de Mestrado e Doutorado, no período de, no máximo, quatro anos, com ônus para o Município. Além disso, o atual regime jurídico do servidor municipal faculta o afastamento para qualificação profissional em programa de treinamento regularmente instituído e de interesse da Administração, quando devidamente autorizado. Sem qualquer prejuízo, o professor poderá ausentar-se do serviço para a doação de sangue, por um dia, para se alistar como eleitor, por dois dias, e por oito dias consecutivos em razão de casamento e de falecimento de familiares (cônjuge, companheiro, pais, madrasta ou padrasto, filhos, enteados, menores sob sua guarda ou tutela e irmãos). É também concedido horário especial ao servidor universitário, quando comprovada a incompatibilidade entre o horário escolar e o de sua lotação, sem prejuízo do exercício do cargo. Entretanto, é exigida a compensação de horário.

Finalmente, os professores não podem solicitar remanejamento para outras Secretarias Municipais, exceto no caso de ocuparem cargos em comissão e desde que o pedido esteja em acordo com a conveniência do titular da Secretaria Municipal de Educação e Cultura.

\section{Critérios de ingresso e evolução na profissão}

Os docentes da rede municipal de Boa Vista são considerados servidores efetivos quando ingressam na carreira por concurso público de provas e títulos e cumprem um estágio probatório de três anos, submetidos a processos semestrais de avaliação do desempenho funcional. Desde 2009, quando o novo PCCR foi instituído, é obrigatória a comprovação 
da formação em nível superior, licenciatura plena, mediante diploma expedido por Instituição de Ensino Superior credenciada e registrado em órgão competente, acompanhado do histórico escolar.

Apesar de presente na atual estrutura da carreira, não é mais permitida a realização de concurso público para o cargo de Professor de Educação Básica (PEB) da Classe I - Nível 1, cujo grau de formação é o magistério de nível médio, já que contraria o requisito de formação para o ingresso. Entretanto, até 2009, era possível ingressar no quadro de funcionários com o magistério de nível médio, o que explica a grande quantidade de professores, na rede, com essa formação - $68 \%$ do quadro, de acordo com os dados do Censo Escolar de 2009. Além disso, os cargos de Especialista em Educação e de Secretário de Escola fazem parte de um Grupo Ocupacional em extinção, desde $2003^{11}$.

A respeito da exigência de nível superior para o ingresso na carreira, pode-se notar a intenção do legislador de Boa Vista de seguir o princípio contido na LDB de adotar a formação em nível superior para todos os professores da educação básica, deixando para trás a possibilidade de contratação de docentes com formação em nível médio, indicada na Lei, ao que parece, como possibilidade a ser superada (LDB/96, Art. 62 e Art. $\left.87, \S 4^{\circ}\right)$. Entretanto, a ambiguidade presente na LDB pode contribuir para que a condição de ingresso em Boa Vista venha a ser objetada, abrindo possibilidade para interpretações favoráveis a candidaturas de inscritos com formação de nível médio, na modalidade normal, pela compreensão de que esses candidatos estão legalmente amparados e aptos para o cargo, tornando questionável o impedimento de sua inscrição.

Os resultados dos concursos têm validade de dois anos e podem ser prorrogados uma única vez, por igual período. Os candidatos com deficiências têm assegurado o direito de inscrição. A eles são reservadas $10 \%$ das vagas e, no caso do não preenchimento, outros concursados

11 De acordo com a Lei ${ }^{\circ}$ 1145, Art. 5, inciso VIII, Grupo Ocupacional se define pelo "conjunto de categorias funcionais reunidas segundo a correlação e afinidade existentes entre elas quanto à escolaridade exigida e/ou ao grau de conhecimento". No que toca aos conceitos de classe e nível, que qualificam o cargo de Professor de Educação Básica, o plano estrutura a carreira em classes de capacitação, de acordo com o grau de instrução do professor, e estabelece cinco classes: a primeira refere-se à titulação de ensino médio completo, passando sucessivamente pela titulação em licenciatura plena, pela especialização lato sensu, por mestrado e por doutorado. Cada uma das classes compreende 15 níveis, que estão relacionados com a progressão salarial dos professores, a ser detalhada adiante. 
aprovados e classificados podem ingressar na carreira. A competência para realizar os concursos é da Secretaria Municipal de Administração e Recursos Humanos, que pode, por sua vez, delegar a condução dos processos seletivos a uma instituição pública ou privada.

$\mathrm{O}$ atual plano estrutura a carreira do magistério em cinco classes, de acordo com a formação específica do professor, evidenciando que o posicionamento na carreira é definido pelo nível de qualificação do docente. Os cinco cargos são: 1) Professor da Educação Básica (PEB) Classe I, com magistério médio - cargo em extinção à medida que for comprovada a habilitação dos professores da rede em cursos de licenciatura plena de nível superior; 2) PEB Classe II, com Licenciatura Plena; 3) PEB Classe III, com Pós-Graduação Lato Sensu na área de Educação e carga horária mínima de 360 horas - nota-se que em Boa Vista a especialização é tratada como mais uma classe na carreira; 4) PEB Classe IV, com Mestrado na área de Educação; e 5) PEB Classe V, com Doutorado na área da Educação. Cada uma das classes compreende 15 níveis $(\mathrm{N})$, ou faixas salariais, designadas pelos números cardinais de 1 a $15^{12}$. Assim, a estrutura atual da carreira do magistério municipal de Boa Vista tem a seguinte configuração:

\section{QUADRO 1}

Estrutura da carreira de professores municipais - EB, Boa Vista

\begin{tabular}{c|c|c|c}
\hline CARGO & FORMAÇÃO & CLASSE & NÍVEL (N1 A N15) \\
\hline \multirow{2}{*}{$\begin{array}{c}\text { Professor } \\
\text { Público da EB } \\
\text { da Prefeitura }\end{array}$} & Magistério médio (PEB I) & I (em extinção) & 1 A 15 \\
\cline { 2 - 4 } Municipal de & Licenciado (PEB II) & II & 1 A 15 \\
\cline { 2 - 4 } Boa Vista (PEB) & Mestre (PEB IV) & III & 1 A 15 \\
\cline { 2 - 4 } & Doutor (PEB V) & V & 1 A 15 \\
\hline
\end{tabular}

Fonte: Dados do estudo.

Os professores concursados ingressam na carreira no cargo de PEB - Classe II, Nível 1, o nível inicial do cargo para o qual pleiteiam vaga. Para adquirir estabilidade os docentes ficam submetidos a um período 12 Ainda de acordo com a Lei $n^{\circ} 1145$, Art. 5 , inciso V, Categoria ou Faixa Salarial tem a seguinte definição: "instrumento que contém referências salariais e possibilita progressão funcional horizontal e promoção por titulação vertical do servidor, delimitada por valores mínimos, intermediários e máximos e identificada por algarismos romanos". 
de estágio probatório de três anos, a contar da data do início do exercício de sua função. Como condição para tal estabilidade, os professores têm seu desempenho acompanhado e avaliado por uma comissão, que leva em conta a aptidão e as capacidades dos servidores para o desempenho do cargo. Se não preencherem os requisitos necessários dessa avaliação, são exonerados.

Como visto, a estrutura dos cargos está vinculada à titulação, o que parece revelar a preocupação e o incentivo da SEMEC em relação à formação de seus quadros. Entretanto, a evolução funcional pela titulação não ocorre de forma automática, como se verá com mais detalhes adiante, mas depende de uma avaliação de desempenho do servidor. Como os cargos se diferenciam pela titulação, outro ponto que merece destaque é a dispersão entre os vencimentos básicos, em um mesmo cargo e, também, entre os diferentes cargos, para aferir o grau de atratividade da carreira e de incentivo à titulação ${ }^{13}$.

A dispersão pode ser definida como a distância entre a menor e a maior remuneração de uma determinada categoria profissional. Dutra Júnior et al. (2000, p. 131), em documento publicado pelo MEC/ FUNDESCOLA, com orientações aos municípios para a elaboração de planos de carreira, definem a menor remuneração como o vencimento básico, sem acréscimo de qualquer vantagem, e a maior remuneração a que corresponde ao vencimento final da carreira acrescido do máximo possível de vantagens. Afirmam ainda que:

[...] a dispersão elevada pode representar baixos níveis de remuneração inicial na carreira, o que tende a dificultar o recrutamento de profissionais qualificados. Ao contrário, dispersão reduzida, embora possibilite níveis iniciais mais altos de remuneração, pode resultar em uma carreira desestimulante, na medida em que a progressão e as vantagens acrescentem valores pecuniários insignificantes ao vencimento básico do magistério. É preciso, pois, encontrar o ponto de equilíbrio, de modo que a carreira seja atraente desde o seu início e que a progressão funcional e as vantagens pecuniárias representem compensação financeira satisfatória (DUTRA JÚNIOR et al., 2000, p.131) 
Considerando a definição de dispersão salarial de Dutra Júnior et al. (2000), mas aplicando-a, inicialmente, apenas ao vencimento básico, nota-se na tabela de vencimentos presente no PCCR (abaixo) que a distância entre o menor e o maior vencimento de um mesmo cargo é sempre equivalente a $98 \%$. Além disso, todo o professor recebe um adicional de $1 \%$ ao ano, sobre o vencimento base, o que faz com que essa distância cresça quanto maior for o tempo de permanência na carreira. Se, por um lado, a diferença de $98 \%$ está contida nos limites estabelecidos na Proposta de diretrizes nacionais para a carreira e a remuneração do magistério público (MEC, 1995) e do Parecer nº 02/1997 (CEB/CNE, 1997 - não homologado pelo MEC), em que a proporção deveria ser de $50 \%$ a 100\% (cf. DUTRA JÚNIOR et al., 2000, p. 132 e 133), por outro lado, se o anuênio for considerado junto ao vencimento essa diferença ultrapassará as recomendações.

Outra ponderação possível é sobre a diferença de vencimentos base entre os cargos de ingresso na carreira atualmente (PEB II N1) e aquele que reflete o topo (PEB V N15). Verifica-se que a distância é superior a $144 \%$, proporção significativamente maior que o indicado nos documentos, mesmo sem considerar vantagens e benefícios acumulados, o que parece ser um estímulo à titulação. Se considerado, no entanto, o vencimento inicial do professor de nível médio de formação (cargo em extinção) e compará-lo ao vencimento do doutor em final de carreira, a distância sobe para cerca de $190 \%$.

VALORES DE VENCIMENTO BÁSICO DO PLANO DE CARGOS, CARREIRA E REMUNERACÃO DO QUADRO EFETIVO DO PROFESSOR PÚBLICO DA EDUCACÁO BÁSICA DA PREFEITUTA MUNIPAL DE BOA VISTA, RR

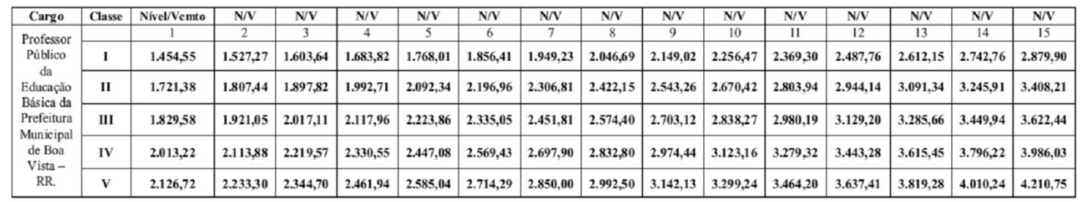

Fonte: Lei n 1145 , de 20 de maio de 2009, anexo I (tabela II)

Nota: Valores vigentes a partir de setembro de 2009, após o enquadramento dos profissionais da educação municipal na Lei ${ }^{\circ} 1145 / 2009$, pelo decreto $n^{\circ} 2025 / P$, de 20 de agosto de 2009. Valores referentes à jornada de 25 horas semanais.

13 De acordo com a Lei no 459/98 (Arts. 43 e 44), vencimento é definido como "a retribuição pecuniária pelo exercício de cargo público, com valor fixado em lei" e a remuneração é considerada como "o vencimento do cargo efetivo, acrescido das vantagens pecuniárias permanentes, estabelecidas em lei". 
Com isso, nota-se que a dispersão salarial, na rede municipal de Boa Vista, pode ser classificada como elevada, um fator de estímulo à permanência do quadro do magistério municipal, na medida em que, ao progredirem por tempo ou titulação, os docentes acrescentarão à sua remuneração valores significativos em relação ao vencimento base inicial. Entretanto, considerando que quanto maior a diferença entre os níveis de remuneração inicial e final na carreira, maior a dificuldade do recrutamento de profissionais qualificados, pode-se inferir que este fato colabora para explicar os dados do Censo 2009 que mostram que $68 \%$ dos profissionais da rede não possuem formação em nível superior. Somese a isso o fato de que os vencimentos iniciais, que hoje não parecem baixos, começaram a vigorar apenas partir de setembro de 2009. Antes disso, eram significativamente inferiores: $\mathrm{R} \$ 454,55$ para PEB I N1 (valor inferior ao do salário mínimo, na época de $\mathrm{R} \$ 465,00)$, e $\mathrm{R} \$ 721,38$ para PEB II N1 ${ }^{14}$, ambos os montantes inferiores ao Piso Salarial Profissional Nacional, instituído em 2008, pela Lei $\mathrm{n}^{\circ} 11.738$, que especifica o valor mínimo de $\mathrm{R} \$ 950,00$ a ser pago em todo o território nacional e a ser reajustado anualmente.

Vale ressaltar que antes de 2007, o vencimento base dos professores era acrescido de $\mathrm{R} \$ 500,00$, a título de abono Fundef. Em 2007, os docentes negociaram com a SEMEC aumentos sucessivos do abono: para $\mathrm{R} \$ 800,00$, em 2007; R\$ 900,00, em 2008; e R\$ 1.000,00, em 2009. Na elaboração do plano, um dos itens da luta salarial dos professores foi a incorporação do abono Fundeb ao vencimento base, acrescendo a ele os $\mathrm{R} \$ 1.000,00$ de abono, visto representar um ganho importante em função de o anuênio incidir sobre esse vencimento. Tal fato se concretizou no novo PCCR, como verificado na tabela acima, expressando outra conquista da categoria.

Não obstante essa conquista, outro ponto deve ser ressaltado: a necessidade de se proporcionar condições concretas para que a evolução funcional por titulação aconteça, visto que, no Estado, apenas sete Instituições de Ensino Superior oferecem o curso presencial de Pedagogia e não há curso de pós-graduação em Educação stricto sensu

14 Valores informados por Sueli Cardozo e presentes em reportagem do jornal eletrônico Roraima em Foco, disponível em: http://www.roraimaemfoco.com/colunistas/variedades-mainmenu-48/16730novos-professores-municipais-tomam-posse-dia-30.html, acessado no dia 24/08/2010. 
reconhecido pela CAPES.

Vale ainda comparar a dispersão dos vencimentos da rede municipal com a dispersão dos vencimentos da rede estadual de Roraima. A TAB. 3 abaixo mostra os vencimentos do magistério estadual, para uma jornada de 25 horas semanais:

TABELA 3

Vencimento do Cargo de Professor 1 - Rede Estadual de Roraima

\begin{tabular}{|c|c|c|c|c|}
\hline $\begin{array}{c}\text { ÁREA DE } \\
\text { ATUAÇÃO }\end{array}$ & CARGO & CLASSE & \multicolumn{2}{|c|}{$\begin{array}{c}\text { NÍVEIS DE } \\
\text { VENCIMENTO }\end{array}$} \\
\hline \multirow{5}{*}{$\begin{array}{c}\text { Ensino } \\
\text { Fundamental, } \\
\text { Ensino Médio, } \\
\text { Educação } \\
\text { Especial, } \\
\text { Educação } \\
\text { Indígena, } \\
\text { Educação de } \\
\text { Jovens e Adultos }\end{array}$} & \multirow[t]{5}{*}{ Professor I } & Especial - Doutorado & Único & $4.400,01$ \\
\hline & & Sênior - Mestrado & $\begin{array}{l}\text { E } \\
\text { D } \\
\text { C } \\
\text { B } \\
\text { A }\end{array}$ & $\begin{array}{l}4.062,22 \\
3.892,96 \\
3.723,70 \\
3.554,44 \\
3.385,18\end{array}$ \\
\hline & & Titular - Lato sensu & $\begin{array}{l}\text { E } \\
\text { D } \\
\text { C } \\
\text { B } \\
\text { A }\end{array}$ & $\begin{array}{l}3.124,79 \\
2.994,58 \\
2.864,39 \\
2.734,19 \\
2.603,98\end{array}$ \\
\hline & & Pleno - Licenciatura & $\begin{array}{l}\text { E } \\
\text { D } \\
\text { C } \\
\text { B } \\
\text { A }\end{array}$ & $\begin{array}{l}2.231,99 \\
2.139,00 \\
2.046,00 \\
1.953,00 \\
1.860,00\end{array}$ \\
\hline & & Júnior - formação EM & $\begin{array}{l}\text { E } \\
\text { D } \\
\text { C } \\
\text { B } \\
\text { A }\end{array}$ & $\begin{array}{l}1.607,23 \\
1.540,27 \\
1.473,30 \\
1.406,33 \\
1.339,37\end{array}$ \\
\hline
\end{tabular}

Fonte: Diário Oficial do Estado de Roraima, publicado em 22/07/2010, p. 9 (disponível em: http:// www.imprensaoficial.rr.gov.br/diarios/doe-20100722. pdf, acessado em 26/11/2010)

Não se trata aqui de discutir a estrutura ou o plano de carreira do magistério estadual de Roraima, mas apenas de comparar a situação remuneratória desses profissionais com os docentes do município. 
Analisando a tabela acima, nota-se que a distância entre o menor e o maior vencimento de professores que possuem um mesmo nível de titulação é de $20 \%$ (comparação que apresenta em Boa Vista proporção de $98 \%$ ). Entretanto, se compararmos a distância entre o vencimento inicial de um professor licenciado e de um professor doutor, essa diferença é de 136\% (já em Boa Vista é de 144\%, com nível superior, e $190 \%$, com nível médio). Essa comparação com a rede estadual reitera a análise de que a dispersão na rede municipal é elevada.

Outra forma de provimento dos cargos, na rede municipal de Boa Vista, é em comissão, deliberada a critério da Administração Municipal e concretizada por ato de nomeação no Diário Oficial. São cargos de livre provimento e exoneração e compreendem as atividades de direção, chefia, assessoramento, assistência e supervisão, obedecendo aos quantitativos estabelecidos em legislação própria. Para o preenchimento dessas vagas, a SEMEC realiza processos seletivos. No que toca à remuneração dos comissionados, é possível optar por receber o valor integral estabelecido para o cargo em comissão, acrescido dos anuênios; receber a diferença entre a remuneração do cargo em comissão e a remuneração do cargo efetivo; ou receber o vencimento do cargo efetivo, acrescido de percentuais específicos da remuneração do cargo em comissão.

Outro aspecto que vale mencionar é a noção, presente no atual PCCR, de "cargo multifuncional", ao atribuir ao trabalho docente uma concepção "ampla e estratégica" e afirmar que engloba todas as especialidades, permitindo que haja flexibilidade para que seus ocupantes exerçam atribuições diversificadas. Essa noção se fortalece, em 2009, pois para o ingresso efetivo na rede, os contratados passam a compor um único Grupo Ocupacional, distintamente do que ocorria sob o PCCR de 2003, quando havia, na rede, dois grupos: um que tinha como requisito a formação em nível médio, na modalidade normal, e o outro composto por licenciados com nível superior completo. Atualmente, além do nível de formação, o plano afirma que o Grupo Ocupacional reúne as categorias funcionais também pelo grau de conhecimento de seus componentes. A noção de cargo multifuncional permite a inclusão, 
no PCCR, dos docentes da EI que têm sua remuneração fixada em função de sua qualificação, sem distinções entre as etapas de ensino, o que parece valorizar esse grupo de profissionais. É preciso frisar, no entanto, que esse avanço tem sido acompanhado pelo Ministério Público de Roraima, que, em 2009, coibiu a prática frequente de contratação de docentes municipais para a educação infantil em regime temporário, no qual o professor recebia remuneração inferior à do servidor estatutário ${ }^{15}$.

No que toca à evolução funcional, há, no PCCR de Boa Vista, duas vias possíveis: a primeira é a Progressão Funcional, que se define pela passagem de um nível $(\mathrm{N})$ para outro imediatamente superior, dentro de uma mesma classe (Lei $n^{\circ} 1145$, art. $5^{\circ}$, inciso IX). Essa evolução é considerada como progressão horizontal e requer interstício de dois anos para uma nova concessão. Considerando a Tabela II, referente ao vencimento base do quadro efetivo do magistério municipal, nota-se que o aumento do valor do vencimento base entre as faixas salariais, na progressão funcional, é de 5\%, para qualquer cargo ou nível de formação do professor. Isso significa, na melhor das hipóteses, que após 25 anos de trabalho a professora que ocupou o mesmo cargo na rede deve estar recebendo, em termos de vencimento base, $71 \%$ a mais do que quando ingressou (estará no Nível 12) e, para chegar ao topo, além de continuar cumprindo todas as exigências de uma avaliação de desempenho funcional, deve permanecer por mais cinco anos na rede. Em relação ao professor, essa diferença sobe para 88,5\%, pois após 30 anos de serviço alcança, na melhor das hipóteses, o Nível 14, precisando de mais um ano para chegar ao topo da carreira.

Além do tempo, a progressão deve respeitar os resultados dos processos de avaliação do desempenho e cumprir com os seguintes requisitos: aprovação em estágio probatório; exercício exclusivo na SEMEC, exceto para cargo em comissão no sistema de educação ou mandato classista; ausência de pena de suspensão e/ou advertência, nos dois anos que antecedem a efetivação da progressão; ausência de faltas e/ou atrasos e saídas antecipadas não justificadas que, somadas, perfaçam mais de 160 horas - também nos dois anos que antecedem

15 Informação fornecida por Sueli Cardozo, em entrevista. 
a data de início do processo de progressão -; ausência de licença ou afastamento por mais de 45 dias, ininterruptos ou intercalados, nos 24 meses que antecedem a data de início do processo de progressão; não ter gozado licença sem vencimento nos dois anos, que só deve ser concedida após este prazo; não estar afastado para exercício de mandato eletivo ou atividade política, no período de quatro anos que antecede a publicação do ato da concessão da progressão; não estar afastado para acompanhar cônjuge ou companheiro, no período de cinco anos que antecede a data da publicação do ato da concessão da progressão; e não ter sido preso por decisão judicial transitada em julgado, ao longo dos quatro anos que antecedem a data da publicação do ato da concessão da progressão.

Em um plano de carreira, é desejável que número de classes e o interstício para promoção sejam definidos considerando a possibilidade de uma parcela significativa dos docentes alcançarem as etapas finais da carreira, sem, contudo, permitir que cheguem ao topo muito rapidamente, tornando parte de sua vida funcional desestimulante. Assim, o número de classes deve ser compatível com a expectativa de duração da vida profissional do magistério, com interstícios que garantam o cumprimento, com qualidade, dos requisitos exigidos para a promoção. Vale lembrar que a aposentadoria voluntária pode ser requerida pelos professores após 30 anos de serviço e 55 anos de idade e pelas professoras após 25 anos de serviço e 50 anos de idade, e que a aposentadoria compulsória dá-se aos 70 anos de idade.

Considerando que cada cargo da rede apresenta 15 faixas salariais e que o interstício para a progressão entre as faixas é de dois anos, isto aliado à avaliação de desempenho e ao estágio probatório de três anos, ou seja, na melhor das hipóteses o professor consegue chegar ao topo da carreira após 31 anos de magistério, tem-se que, apesar de longa e de depender de procedimentos de avaliação de desempenho, a amplitude da carreira deve permitir a uma parcela significativa de docentes chegar próxima ao final da carreira, visto que os professores municipais são relativamente jovens (50\% têm até 33 anos de idade) e podem permanecer trabalhando para além do tempo e da idade 
referentes à aposentadoria voluntária.

O segundo tipo de movimentação é chamado de Promoção por Titulação e se define pela passagem de uma classe para outra imediatamente superior, de acordo com a titulação acadêmica do servidor (Lei $n^{\circ} 1145$, art. $5^{\circ}$, inciso X). Em geral, a titulação é um dos principais fatores que contam para a diferença de remuneração entre os profissionais do magistério. Tomando os dados da Tabela II, nota-se que são diferentes as proporções de aumento do vencimento base entre os diversos cargos de professor, na rede municipal de Boa Vista: de PEB Nível I (ensino médio, em extinção), para PEB Nível II (ensino superior), a diferença é de mais de $18 \%$ a mais acentuada entre os cargos, entretanto, inferior ao teto estipulado pela Resolução $n^{\circ}$ 03/97 (art. 6,$\left.V\right)$, que dispõe que a remuneração dos docentes com licenciatura plena não deva ultrapassar em mais de $50 \%$ à dos formados em nível médio. A diferença do vencimento base de PEB Nível II para PEB Nível III (especialização) diminui, é de cerca de 6\%; a de PEB Nível III para PEB Nível IV (mestrado) sobe, é de 10\% e, finalmente, a de PEB Nível IV para PEB Nível V (doutorado) é a menor diferença, com pouco mais de $5 \%$.

Essa evolução é considerada vertical e, além da devida comprovação da titulação, o servidor deve, também, apresentar resultados satisfatórios na avaliação de desempenho funcional e ter cumprido estágio probatório. De acordo com o PCCR, o professor que usar de máfé ou outro artifício, como a apresentação de documento falso, visando ser beneficiado pela promoção por titulação, fica sujeito às penalidades disciplinares e criminais e obrigado a ressarcir os prejuízos decorrentes da verba recebida indevidamente, com juros e correção monetária.

Outra observação pertinente a essa questão, é a de que para além dos cursos de pós-graduação que permitem a mudança de cargo e melhor remuneração, não está previsto no PCCR do município nenhum tipo de promoção funcional para os docentes que realizam atividades de formação continuada em cursos de aperfeiçoamento e atualização profissional, por exemplo, deixando a modalidade de formação não acadêmica sem incentivo financeiro. De acordo com o Parecer nº 9/2009, 
[...] é importante assegurar não apenas a evolução na carreira pela via acadêmica, através da qual os professores que obtenham titulação acadêmica superior àquela exigida para o exercício do cargo que ocupa; é preciso, também, que os entes federados consignem nos planos de carreira a evolução pela via não acadêmica, através da qual são contemplados os docentes que realizam cursos de aperfeiçoamento e atualização profissional e participam de estudos e outras atividades consideradas relevantes para a melhoria da qualidade de seu trabalho, isto é, evoluem dentro do mesmo nível de formação exigido ao exercício do cargo. (BRASIL, 2009).

Uma das pautas que mobilizou os professores quando da elaboração do plano de carreira, segundo informações obtidas em entrevista com a presidente do Sindicato dos Trabalhadores Municipais de Boa Vista (Sintram), Sueli Cardozo, foi a possibilidade de obter vantagens salariais considerando as atividades e cursos de formação não acadêmicos cujas cargas horárias somassem o mesmo número de horas de cursos de pósgraduação. Entretanto, esse pleito não foi acatado pela SEMEC. Apesar disso, Sueli afirma que a Secretaria vem investindo na formação inicial e continuada de seus quadros, buscando parcerias, principalmente, com a Universidade Federal de Roraima e com o Instituto Federal de Educação, Ciência e Tecnologia de Roraima. Outra conquista ressaltada, em relação ao plano de 2003, refere-se ao fim da imposição de um quantitativo de vagas para que a evolução funcional fosse efetivada. Atualmente, basta ao professor apresentar seu título e cumprir com os requisitos da avaliação de desempenho para obter sua promoção.

Como visto, ambas as formas de evolução na carreira - Progressão Funcional e Promoção por Titulação - estão mescladas com procedimentos e critérios de avaliação do desempenho funcional e, de acordo com Sueli Cardozo, essa vinculação foi uma condição imposta pela SEMEC que abriu, entretanto, a negociação para definir os procedimentos e o percentual de pontuação necessários à aprovação dos docentes. Essa imposição está em consonância com as prescrições da LDB/96, que prevê, em seu artigo 67, inciso IV, a "progressão funcional 
baseada na titulação ou habilitação e na avaliação de desempenho" (BRASIL, 1996, grifo nosso).

Em Boa Vista, concluído o estágio probatório, o profissional do magistério fica habilitado à primeira Progressão Funcional e a qualquer Promoção por Titulação. Para a avaliação de seu desempenho, deve ser constituída uma subcomissão temporária de avaliação, na unidade escolar, composta pelo diretor, um professor e o próprio servidor que está sendo avaliado. Além da autoavaliação, realizada pelo servidor, são utilizados diferentes instrumentos, como as avaliações dos membros da subcomissão, a cópia de sua ficha funcional e outras informações existentes. Em cada unidade escolar, ficam arquivados os portfólios dos professores, preenchidos pela subcomissão de avaliação, onde são registrados os apontamentos avaliativos. A responsabilidade pelo registro desses dados é da gestão escolar ou chefia imediata.

Para regulamentar esse processo, estão definidos critérios subjetivos e objetivos de avaliação, estabelecidos no Decreto n. ${ }^{\circ}$ 210/E, de 07 de dezembro de 2009, que cria o Sistema de Avaliação de Desempenho e uma Comissão Permanente de Avaliação e Desempenho do Estágio Probatório e Avaliação para concessão de Progressão Funcional e Promoção por Titulação dos Profissionais do Magistério, a COPAM, e no Decreto n ${ }^{\circ} 218 / \mathrm{E}$, de 23 de dezembro de 2009, que aprova o regulamento do sistema de avaliação de desempenho para efeito do estágio probatório, promoção por titulação e progressão funcional dos profissionais do magistério. Apesar de o decreto ser de dezembro de 2009, a COPAM só entrou em atividade três meses depois, em março 2010, o que atrasou a análise dos processos de promoção e progressão formalizados junto à Secretaria Municipal de Administração e Gestão de Pessoas (SMAG), bem como a avaliação de servidores em estágio probatório ${ }^{16}$.

Há quatro eixos que balizam os critérios subjetivos da avaliação do desempenho docente. São eles: 1) Criatividade, em que se considera a capacidade do docente para inovar em relação às práticas didáticas

16 Informações dadas por Sueli Cardozo e disponíveis no jornal Roraima em Foco, no endereço eletrônico: http://www.roraimaemfoco.com/colunistas/geral-mainmenu-45/17622-prefeito-iradilson-recebe-acomissao-permanente-de-avaliacao-do-magisterio.html, consultado em 20/08/2010. 
e pedagógicas. 2) Participação efetiva nas atividades pedagógicas, em que se considera a capacidade de desenvolver essas atividades, em equipe, mantendo uma postura profissional participativa e colaboradora, inclusive em relação às atividades de articulação da escola com as famílias e a comunidade; participar da elaboração da proposta pedagógica do estabelecimento de ensino; elaborar e cumprir plano de trabalho; estabelecer estratégias de recuperação para os alunos de menor rendimento; ministrar os dias letivos e horas-aula estabelecidas, além de participar integralmente dos períodos dedicados ao planejamento, à avaliação e ao desenvolvimento profissional. 3) Relacionamento de respeito com os demais profissionais e com os alunos, em que se considera o comportamento do professor no trato com os demais profissionais e com os alunos, em termos de relacionamento, lisura, respeito e solidariedade. 4) Dinâmica, competência e prática inovadora na atividade profissional, em que se considera a capacidade criativa do docente, na elaboração e execução de projetos pedagógicos, e metodologia que resultem na melhoria e qualidade da aprendizagem.

Como a própria adjetivação dos critérios evidencia, a subjetividade dessa etapa de avaliação do desempenho pode dar margem a apreciações imparciais e tendenciosas, por parte dos membros da subcomissão, visto a dificuldade de se mensurar, por exemplo, o que é e o quanto de criatividade, o comportamento ou o dinamismo de um professor podem proporcionar de fato algum impacto positivo para promover mais qualidade na relação ensino-aprendizagem. Sem contar que a valorização profissional assentada em características pessoais, da esfera privada, contradita a própria natureza do cargo público e as condutas que devem caracterizá-lo, como a observância de normas previamente estabelecidas e a não submissão à vontade pessoal de superiores. Nesse sentido, parece que os itens subjetivos da avaliação contribuem para a elevação do risco de tornar esse processo um instrumento de controle do trabalho do professor e não de valorização da profissão docente. É um tipo de tratamento e de relação funcional que evidencia a tendência de incorporação de traços característicos da administração pública de tipo gerencial, ao valorizar servidores que 
adotam comportamentos e valores próximos daqueles esperados no setor privado (BRESSER PEREIRA, 1996).

No que toca aos oito parâmetros referentes aos critérios objetivos, acionados ao final de cada semestre, tem-se a seguinte pauta de avaliação: 1) Assiduidade e pontualidade, que exige que o servidor compareça habitualmente ao serviço, desempenhando as funções que lhe são atribuídas. 2) Disciplina, em que são aferidos o cumprimento de ordens e normas, cooperação e participação em trabalhos em equipe e receptividade às críticas. 3) Capacidade de iniciativa, que avalia a criatividade, espontaneidade para aprender outros serviços e auxiliar os colegas, interesse, capacidade de tomar decisões, facilidade na resolução de problemas e a contribuição pela experiência profissional para o desenvolvimento organizacional. 4) Responsabilidade, medida pelo comprometimento, amadurecimento profissional, dedicação e confiança, agilidade e zelo pelo patrimônio da instituição. 5) Qualidade, em que se consideram os aspectos de dinamicidade e apuro com que o docente atua nos trabalhos didáticos, paradidáticos e gerenciais, constatados no portfólio e nos resultados obtidos. 6) Ética profissional, aferindo se o servidor tem consciência de que seu trabalho é regido por princípios éticos que se materializam na adequada prestação dos serviços públicos; para isso deve manter a ética de sua conduta moral com dignidade, decoro, zelo, eficácia e consciência dos princípios morais, no exercício do cargo ou função, ou fora dela. 7) Conhecimento profissional, em que se considera o grau de competência, em relação ao conhecimento que possui das técnicas didáticas e pedagógicas, constado no portfólio onde se registra a participação do profissional do magistério nos diversos eventos sociais e científicos. 8) Atendimento, aferindo o grau de interesse e disponibilidade do servidor para prestar atendimento aos alunos, durante e após as aulas, e aos pais dos estudantes.

Como visto, mesmo nos itens qualificados como objetivos é possível notar a carga de subjetividade e a dificuldade de se estabelecer parâmetros para a mensuração de características como compromisso, conduta moral, decoro, grau de interesse e disponibilidade, entre outros. Ambos os instrumentos de avaliação parecem precários e pouco precisos para aferir 
o desempenho qualificado do profissional e, a depender do contexto em que venham a ser aplicados, podem ganhar um caráter persecutório ou consistir em mera formalidade, pouco contribuindo para a definição do mérito profissional ou a contribuição para melhoria da educação.

Há vários obstáculos para se atrelar a evolução da remuneração do professor à avaliação de seu desempenho, tal como a dificuldade de precisar exatamente o que é o desempenho docente e de identificar como esse desempenho afeta a qualidade educacional e o aprendizado do aluno. Nesse sentido, Morduchowicz (2003, p. 23) alerta também para o fato "de que o trabalho realizado pelos docentes, além de ter múltiplos objetivos, é um serviço cujos resultados são intangíveis, difíceis de quantificar e de medir". Não se trata de negar a necessidade de avaliar o trabalho docente, mas de considerar qual o benefício de atrelar o resultado desse processo à definição de acréscimos salariais e à evolução na carreira.

A avaliação docente, em Boa Vista, é composta também pelos seguintes indicadores educacionais: a) Taxa de Rendimento Escolar, definida pela porcentagem igual ou superior a $70 \%$ dos alunos que avançam nos processos de aprendizagem, no segundo e quarto bimestres, em função do número de alunos matriculados e b) Taxa de Reprovação Escolar, definida como a porcentagem de alunos que não avançam nos processos de aprendizagem, em função do número de matriculados. Apesar de as taxas de rendimento, aprovação e reprovação escolar serem parâmetros empiricamente observáveis, é preciso ponderar que o fato de estarem incorporadas à avaliação de desempenho, e esta, por sua vez, incidir sobre a ascensão salarial, pode estimular os docentes a atuarem na avaliação de seus alunos de forma enviesada, objetivando benefícios pessoais.

São considerados aprovados no estágio probatório os servidores que obtiverem desempenho igual ou superior a 54 pontos em um total de 90 pontos possíveis - isto é, 10 pontos para cada um dos nove itens avaliados (vide quadro abaixo). Além disso, o servidor em estágio probatório é avaliado mensalmente, por seis semestres, e se obtiver nota inferior a $60 \%$ dos pontos do total da média das seis avaliações 
semestrais do estágio probatório é considerado reprovado. No caso do servidor efetivo, não é concedida a Progressão Funcional e/ ou Promoção por Titulação àquele que obtiver nota inferior a $60 \%$ da soma dos pontos da avaliação de desempenho.

A soma dos pontos pode atingir notas que variam entre um (01) e 10 (dez) e a elas são atribuídos diferentes conceitos: entre um (01) e quatro (04) o conceito é regular, entre cinco (05) e sete (07) o conceito é bom e entre oito (08) e 10 (dez) é ótimo. O resultado da avaliação do desempenho funcional é consolidado em um Boletim, tal como mostra o QUADRO 2 a seguir:

$$
\text { QUADRO } 2
$$

Boletim de Avaliação de Desempenho

\begin{tabular}{|c|c|c|c|c|c|c|c|}
\hline \multirow{2}{*}{$\begin{array}{l}\text { BOLETIM DE AVALIAÇÃO } \\
\text { DE DESEMPENHO }\end{array}$} & \multicolumn{3}{|c|}{ SUBCOMISSÃO } & \multicolumn{3}{|c|}{ AUTOAVALIAÇÃO } & \multirow[b]{2}{*}{ Médi } \\
\hline & Regular & Bom & Ótimo & Regular & Bom & Ótimo & \\
\hline $\begin{array}{l}01 \text { - Criatividade, Participação, } \\
\text { Relacionamento e Dinâmica } \\
02 \text { - Assiduidade e Pontualidade } \\
03 \text { - Disciplina } \\
04 \text { - Capacidade de Iniciativa } \\
05 \text { - Responsabilidade } \\
06 \text { - Qualidades } \\
07 \text { - Ética Profissional } \\
08 \text { - Conhecimento Profissional } \\
09 \text { - Indicadores Educacionais } \\
\text { Média Final }\end{array}$ & & & & & & & \\
\hline
\end{tabular}

Fonte: Dados do estudo.

As formas de aplicação final das notas são as seguintes: a) a soma da média semestral; b) a soma total dos seis semestres para o estagio probatório e de quatro semestres para avaliação da Progressão Funcional; c) divide-se o resultado do item " $b$ " por seis ou por quatro; d) para ser aprovado, o resultado do item " $c$ " deve ser igual ou superior a 45 pontos, baseando-se que 45 pontos equivalem a $60 \%$ da soma máxima dos nove critérios. Os resultados da avaliação são consolidados em um formulário, depois de computados os pontos apurados aritmeticamente, com o seguinte formato: 


\section{QUADRO 3}

Consolidação dos resultados do professor

Nome do Profissional:

\begin{tabular}{|c|c|c|}
\hline Cargo: & Classe: & Matrícula: \\
\hline \multicolumn{3}{|c|}{ Unidade Escolar/Subcomissão de Avaliação } \\
\hline Fator de Avaliação & & Pontos \\
\hline \multicolumn{3}{|l|}{ Subjetivos } \\
\hline \multicolumn{3}{|c|}{01 - Criatividade, Participação, Relacionamento e Dinâmica } \\
\hline \multicolumn{3}{|l|}{ Objetivos } \\
\hline \multicolumn{3}{|c|}{02 - Assiduidade e Pontualidade } \\
\hline \multicolumn{3}{|l|}{03 - Disciplina } \\
\hline \multicolumn{3}{|c|}{04 - Capacidade de Iniciativa } \\
\hline \multicolumn{3}{|l|}{05 - Responsabilidade } \\
\hline \multicolumn{3}{|l|}{06 - Qualidades } \\
\hline \multicolumn{3}{|l|}{07 - Ética Profissional } \\
\hline 08 - Conhecimento $\mathrm{P}$ & & \\
\hline
\end{tabular}

\section{Total de Pontos}

Data_______

Subcomissão de Avaliação

Assinatura

Fonte: Dados do estudo.

Cabe à Secretaria Municipal de Educação e Cultura orientar, supervisionar e coordenar os processos de avaliação de desempenho dos profissionais do magistério, bem como realizar inspeções e fiscalizar o cumprimento da legislação pertinente às avaliações. A concessão da Progressão Funcional ou da Promoção por Titulação depende do relatório de avaliação expedido pela referida comissão, submetido à autoridade da SEMEC.

Pode-se observar que o PCCR atribui bastante valor à avaliação do desempenho, ao vincular as duas formas de evolução funcional a ela. Entretanto, se não houver investimento da SEMEC na formação inicial e continuada de seu corpo docente, ficará a cargo dos próprios 
professores a responsabilidade e as iniciativas de melhoria e superação de suas dificuldades. Além disso, a aferição do desempenho funcional promove uma cultura de avaliação que, se não estiver assentada em processos transparentes e objetivos, pode prejudicar ao invés de colaborar com o desenvolvimento profissional dos servidores, com a melhoria da qualidade de ensino e com a valorização do magistério.

\section{Composição da remuneração do magistério público municipal de Boa Vista}

Em relação à remuneração, o atual PCCR define que os dispositivos constantes do plano anterior (2003) foram transpostos e contabilizados para aplicação das vantagens pessoais, na tabela de vencimentos base do magistério. Em outras palavras, informa que, em acordo com a Resolução $n^{\circ} 2 / 2009$, definiu o vencimento dos profissionais do magistério de Boa Vista considerando as prescrições da lei do FUNDEB, na medida em que incorpora à remuneração o valor do abono relativo ao fundo, como visto anteriormente.

Entretanto, de acordo com Sueli Cardozo, a mudança de plano também acarretou perdas para a remuneração docente. $\mathrm{O}$ adicional previsto, no plano de 2003, para o exercício da docência a alunos portadores de necessidades educacionais especiais deixa de existir, no atual PCCR, e a justificativa da SEMEC para tanto é que compreende que qualquer docente, hoje, deve estar apto a lidar com a diversidade. Além disso, também caiu o adicional para o exercício da docência em escolas da zona rural, que era de $30 \%$ sobre o vencimento base do professor em sala de aula. Esse benefício foi parcialmente recuperado pelos professores, recentemente, mas com uma alíquota menor, de 15\% sobre o atual vencimento base (cf. Lei n. 1235, de 31 de março de 2010).

Além disso, o magistério faz jus a uma série de gratificações previstas no regime jurídico dos servidores públicos civis do município, tais como: a gratificação natalina, corresponde a um doze avos da remuneração por mês de efetivo exercício no respectivo ano; adicional de férias, correspondente a um terço da remuneração do período das férias, independente de solicitação; o adicional por tempo de serviço, 
à razão de $1 \%$, por ano de serviço público efetivo, incidente sobre o vencimento a partir do mês em que completar o anuênio; acréscimo de $25 \%$ no valor-hora, quando trabalhar entre as 22 horas de um dia e as 5 horas do dia seguinte, computando-se cada hora como 52 minutos e 30 segundos; adicional de insalubridade, de 5\%,10\% e 20\% do vencimento, de acordo com os graus mínimo, médio e máximo estabelecidos no laudo médico-pericial; adicional de periculosidade de $10 \%$, calculado sobre o vencimento do cargo efetivo do servidor; além dos adicionais de salário família, salário maternidade e auxilio reclusão. Entretanto, as disposições presentes no plano não se aplicam aos servidores inativos e aos pensionistas de servidores falecidos.

\section{Considerações Finais}

O PCCR de Boa Vista é um instrumento que permite, ao professor, divisar a trajetória que tem pela frente como profissional do magistério e algumas das relações e condições de trabalho presentes no Sistema Municipal de Educação. Após a aprovação em concurso público e um período probatório de três anos, o docente adquire estabilidade e faz jus a dois tipos de promoção para a ascensão dentro de sua carreira - por titulação e por tempo de serviço - aliadas a uma avaliação de desempenho funcional. A estabilidade e a promoção interna caracterizam o regime de trabalho burocrático clássico das administrações públicas profissionais, o que pode estimular os jovens para a carreira docente, visto que o universo atual de relações sociais e de trabalho tem estado crescentemente inseguro e precário.

Entretanto, as características presentes na avaliação de desempenho funcional de Boa Vista agregam a esse modelo burocrático traços da administração pública de tipo gerencial, em que se estabelece um controle por resultados, a posteriori, ao invés de normas rígidas, com controle sistemático dos processos administrativos e de trabalho - uma mudança que tende a promover situações instáveis e incertas de trabalho.

A qualidade do desempenho docente tem sido determinada, em Boa Vista, por uma série de elementos, alguns deles objetivos, ainda que 
problemáticos, tais como as taxas de fluxo escolar, informações sobre a pontualidade e a assiduidade docente, a observância de normas, mas, também, por ideais subjetivos de mérito pessoal e de performances individuais, que não permitem, aos profissionais, o conhecimento objetivo dos critérios que fundamentam o êxito ou o fracasso de sua atuação. $\mathrm{O}$ uso de elementos subjetivos para a autocrítica pode levar o professor a perder o referencial de identidade e a compreensão da complexidade de sua profissão, ficando à mercê da incerteza, dominado pelo receio de ser coagido, censurado e repreendido, além de estar sob constante pressão.

Essa forma de controle do trabalho docente não está apenas mediada pelas relações de poder autoritárias e hierárquicas, mas tem instigado, também, a intensificação de seu trabalho, requisitando maior participação e compromisso do profissional no cotidiano escolar, sem, contudo, possibilitar um regime de dedicação exclusiva, o que permite - para não dizer estimula - a dupla jornada de trabalho. Essa situação, aliada à cultura do desempenho individual, pode levar o professor ao estresse e ao sofrimento no trabalho.

Outros fatores que poderiam desestimular os pretendentes à carreira docente são a ausência de reconhecimento de atividades não acadêmicas para a evolução funcional, fazendo da exigência de formação inicial para o ingresso na carreira a principal estratégia de profissionalização do quadro docente de Boa Vista, e a classificação funcional de ingresso (PEB II, N1), que só considera a titulação em nível de pós-graduação depois do período probatório, a despeito de a carreira estar estruturada na titulação.

Entretanto, há fatores concretos no PCCR que promovem a atratividade, tais como a possibilidade de os profissionais alcançarem as classes finais da carreira; a dispersão salarial elevada, que permite acréscimos significativos ao vencimento base, ao longo da carreira, com as progressões e promoções; a possibilidade de afastamento para a formação acadêmica, sem prejuízo para o funcionário, o que significa adicionais significativos ao vencimento base; a incorporação do abono do Fundeb ao vencimento base, sobre o qual incide o anuênio; e a ausência de quantitativo de vagas para a concretização de qualquer evolução funcional.

Além disso, é preciso considerar que pertencer ao mercado de 
trabalho formal em uma cidade onde tal condição é inexistente para mais da metade da população, os professores boa-vistenses apresentam remuneração superior a três salários mínimos, com uma jornada de 25 horas de trabalho semanal, fazendo parte, portanto, do terço da população que apresenta maior rendimento, na cidade. Considerando, ainda, que boa parte desses profissionais tem dupla jornada de trabalho, a situação salarial e trabalhista do magistério deve sem dúvida constituirse como fator de estímulo e atratividade para os futuros postulantes à carreira docente, no município de Boa Vista. 


\section{Referências}

BRASIL. Constituição (1988). Constituição da República Federativa do Brasil. Brasília: Senado Federal, 1988.

BRASIL. Lei n. 9.394 de 20 de dezembro de 1996. Dispõe sobre as diretrizes e bases da educação nacional. Diário Oficial da União, Brasília: v.135, n. 248, 23 dez. 1996.

BRASIL. Lei n. 9.424 de 24 de dezembro de 1996. Dispõe sobre o Fundo de Manutenção e Desenvolvimento do Ensino Fundamental e de Valorização do Magistério, e dá outras providências. Diário Oficial da União, Brasília: n. 250, 26 dez. 1996.

BRASIL. Ministério da Educação. Conselho Nacional de Educação. Câmara de Educação Básica. Resolução n. 3 de 8 de outubro de 1997. Fixa diretrizes para Novos Planos de Carreira e de Remuneração para o Magistério dos Estados, do Distrito Federal e dos Municípios. Brasília, 1997b. Disponível em: <http:/ / portal.mec.gov.br/cne/ arquivos/pdf/1997/pceb010_97.pdf>. Acesso em: 09 nov. 10.

BRASIL. Congresso Nacional. Emenda Constitucional n. 19 de 04 de junho de 1998. Modifica o regime e dispõe sobre princípios e normas da Administração Pública, servidores e agentes políticos, controle de despesas e finanças públicas e custeio de atividades a cargo do Distrito Federal, e dá outras providências. Disponível em: <http:/ / www.planalto.gov.br/ccivil_03/constituicao/Emendas/Emc/emc19. htm>. Acesso em: 05 out. 2010.

BRASIL. Lei n. 11.494 de 20 de junho de 2007. Dispõe sobre o Fundo de Manutenção e Desenvolvimento da Educação Básica e de Valorização dos Profissionais da Educação, na forma prevista no artigo 60 do Ato das Disposições Constitucionais Transitórias. Altera a Lei $\mathrm{n}^{\circ} 10.195$, de 14 de fevereiro de 2001, revoga dispositivos das Leis $n^{\circ}$ 9. 424, de 24 de dezembro de 1996; da Lei $n^{\circ} 10.845$, de 05 de março de 2000 e lei n ${ }^{0} 10.880$, de 09 de junho de 2004; e dá outras 
providências. Diário Oficial da União, Brasília: 21 jun. 2007.

BRASIL. Lei n. 11.738 de 16 de julho de 2008. Regulamenta a alínea "e" do inciso III do caput do art. $6^{\circ}$ do Ato das Disposições Constitucionais Provisórias, para instituir o piso salarial profissional nacional para os profissionais do magistério público da educação básica. Diário Oficial da União. Brasília, n. 136, 17 jul. 2008. Seção 1, p.1.

BRASIL. Ministério da Educação. Conselho Nacional de Educação. Câmara de Educação Básica. Parecer n. 9, de 02 de abril de 2009. Revisão da Resolução CNE/CEB n. 3/97, que fixa Diretrizes para os Novos Planos de Carreira e de Remuneração para o Magistério dos Estados, do Distrito Federal e dos Municípios. Brasília, 2009a. Disponível em: <http:/ / www.crmariocovas.sp.gov.br/pdf/ diretrizes_p0317-0330_c.pdf>. Acesso em: 25 abr. 2010.

BRASIL. Ministério da Educação. Conselho Nacional de Educação. Resolução CNE/CEB $n^{0} 2$ de 28 de maio de 2009. Fixa as Diretrizes Nacionais para os Planos de Carreira e Remuneração dos Profissionais do Magistério da Educação Básica Pública. Disponível em: <http://portal.mec.gov.br/dmdocuments/resolucao_cne_ ceb002_2009.pdf>. Acesso em: 10 mar. 2010.

BRESSER PEREIRA, L. C. Da administração pública burocrática à gerencial. Revista do Serviço Público, 47(1) jan./abr., 1996. Disponível em: <http:/ / academico.direitorio.fgv.br/ccmw/images/1/1d/ Bresser.pdf>. Acesso em: 10 mar. 2010.

BOA VISTA. Lei ${ }^{\circ} 714$, de 10 de dezembro de 2003. Diário Oficial do Município, Poder Executivo, Boa Vista. Dispõe sobre a estrutura de cargos, carreira e remuneração do quadro de provimento efetivo do grupo magistério público municipal da Prefeitura de Boa Vista - RR. Disponível em: <http://www.boavista.rr.gov.br/files/lei714.pdf>. Acesso em: 12 abr. 2010. 
BOA VISTA. Lei $n^{\circ} 1145$, de 20 de maio de 2009. Diário Oficial do Município, Poder Executivo, Boa Vista. Dispõe sobre a estrutura de cargos, carreira e remuneração do quadro de provimento efetivo do professor público da educação básica da prefeitura municipal de Boa Vista - RR, e dá outras providências. Disponível em: <http:/ / www. boavista.rr.gov.br/ARQ/up/diario_2462.pdf>. Acesso em: 10 mar. 2010.

BOA VISTA. Lei $n^{0} 784$, de 06 de junho de 2005. Dispõe sobre o sistema municipal de ensino e dá outras providências. Disponível em: <http://www.boavista.rr.gov.br/ARQ/up/diario_2462.pdf>. Acesso em: 12 abr. 2010.

BOA VISTA. Decreto $n .^{\circ}$ 210/E, de 07 de dezembro de 2009. Cria o Sistema de Avaliação de Desempenho e uma Comissão Permanente de Avaliação e Desempenho do Estágio Probatório e Avaliação para concessão de Progressão Funcional e Promoção por Titulação dos Profissionais do Magistério. Disponível em: <http:/ / www.boavista. rr.gov.br/ARQ/up/diario_2594.pdf>. Acesso em: 10 mar. 2010.

BOA VISTA. Decreto $n^{\circ} 218 / E$, de 23 de dezembro de 2009. Aprova o regulamento do sistema de avaliação de desempenho para efeito do estagio probatório, promoção por titulação e progressão funcional dos profissionais do magistério. Disponível em: <http:/ / www.boavista. rr.gov.br/ARQ/up/diario_2606.pdf>. Acesso em: 10 mar. 2010.

BOA VISTA. Lei $n^{\circ} .1235$, de 31 de março de 2010. Altera dispositivos da lei municipal $n^{\circ} 1145$, de 20 de maio de 2009, acrescenta parágrafos em seu art. 20, e dá outras providências. Disponível em: <http:/ / www. boavista.rr.gov.br/ARQ/up/diario_2669.pdf>. Acesso em: 10 mar. 2010.

DUTRA JÚNIOR et. al. Plano de carreira e remuneração do magistério público: LDB, FUNDEF, Diretrizes nacionais e nova concepção de carreira. FUNDESCOLA/MEC Brasília: 2000.

GATTI, Bernardete A.; BARRETO, Elba de Sá. Professores do Brasil: impasses e desafios. Brasília: Unesco. 2009. 
GOUVEIA, A. B.; CRUZ, R. E. ; CAMARGO, R. B.; OLIVEIRA, J. . Condições de trabalho docente, ensino de qualidade e custo-aluno ano. Revista Brasileira de Política e Administração da Educação, v. 22, p. 253-276, 2006.

LUCE, Maria Beatriz; FARENZENA, Nalu. Financiamento da educação infantil e do ensino fundamental nos municípios do Rio Grande do Sul: estudo das fontes e usos de recursos e dos custos educacionais. Porto Alegre: UFRGS, 1998.

MORDUCHOWICZ, Alejandro. Carreiras, incentivos e estruturas salariais docentes. Rio de Janeiro: PREAL Brasil, 2003.

OIT/UNESCO. Recomendación relativa a la situación del personal docente. Conferencia Intergubernamental Especial sobre la Situación del Personal Docente. Paris, 5 de outubro de 1966. Disponível em: <http://www.ei-ie.org/statusofteachers/file/\%281966\%29\%20 UNESCO-ILO \% 20Recommendation \%20on \%20the \%20Status $\% 20$ of $\% 20$ Teachers \%20es.pdf $>$. Acesso em: 10 mar. 2010.

PARO, Vitor Henrique. O Custo do Ensino Público no Estado de São Paulo. Cadernos de Pesquisa. Fundação Carlos Chagas, São Paulo, n. 43, p. 3-29, 1982.

PINTO, José Marcelino de Rezende. O custo aluno qualidade na legislação. In: Gouveia, Andréia B.; Souza, Ângelo R.; Tavares, Taís M.. (Org.). Conversas sobre financiamento da educação. Curitiba: Editora da UFPR, 2006, v. 1, p. 7-312.

SABOIA, J. e SABOIA, Ana L. Caracterização do setor informal a partir dos dados do Censo Demográfico do Brasil de 2000. In: Política Geral de Emprego: Necessidades, Opções, Prioridades, 2004, Brasília. Trabalho Decente. Brasília: OIT, 2004. v. 1. Disponível em: <http:/ / www.redcelsofurtado.edu.mx/archivosPDF/saboia2.pdf $>$. Acesso em: 10 mar. 2010. 
SOUZA, Ana H. C. de. População Indígena de Boa Vista/RR: uma análise sócio-econômica. Dissertação de mestrado apresentada no programa de pós-graduação em Economia da Faculdade de Ciências Econômicas da UFRGS. 2009. Disponível em: <http:/ / www.lume.ufrgs.br/ bitstream/handle/10183/18309/000724141.pdf?sequence=1>. Acesso em: 10 mar. 2010.

SOUZA, Luciana S.; SANTOS, Haroldo E. A. dos; SOUZA, Romina B. de L. de. Desenvolvimento humano do município de Boa Vista, RR. Análise, Porto Alegre, v. 19, n. 2, p. 78-92, jul./dez. 2008. Disponível em: <http://revistaseletronicas.pucrs.br/face/ojs/index. php/face/article/viewFile/4860/4157>. Acesso em: 10 mar. 2010.

\title{
Career plan of career and remuneration in Boa Vista (RR): analysis of the teaching work enhancement
}

\begin{abstract}
This paper analyzes the structure of the Career Plan of Municipal Teachers of Boa Vista (RR). It considers the prescriptions of the law which established the current Career Plan aiming at revealing the diversity of achievement of the Teacher Enhancement's Policy. The analysis showed that the salary and the labor situation of teachers are factors of stimulus for future applicants to the profession in that city, despite of the upward movement in their careers is conditioned to a performance evaluation that does little to enhance the teaching.
\end{abstract}

Keywords: teachers' career; professional development; teachers' pay.

Recebido: 18/01/2012

Aprovado: 20/06/2012 